https://doi.org/10.18485/iipe_postkovid.2021.ch2

\title{
BUDUĆNOST EVROPSKE UNIJE NAKON PANDEMIJE KOVID 19: KREIRANJE NOVOG EVROPSKOG NARATIVA
}

\author{
Sanja IVIĆ ${ }^{1}$ \\ Rajko PETROVIĆ2
}

\begin{abstract}
Apstrakt: Pandemija Kovid 19 imala je važan uticaj na unutarpolitičke odnose u Evropskoj uniji, kao i na poziciju Evropske unije kao globalnog aktera. Na unutarpolitičkom planu Unija se suočila sa erozijom principa solidarnosti, kao jednog od njenih temeljnih principa, s obzirom na to da je pri pronalaženju rešenja za zaštitu zdravlja i ekonomija država članica EU dominirao nacionalni, a ne zajednički evropski interes. Glavna teza na kojoj se zasniva ovaj rad jeste da je neophodno da Evropska unija razvije novi narativ zasnovan na pojmu transnacionalne solidarnosti, koji će doprineti većoj efikasnosti, otpornosti i odgovornosti EU. Za razliku od ideje solidarnosti na nivou nacionalnih država, razvijanje ideje evropske solidarnosti treba da obuhvati višeslojnu, nadnacionalnu prirodu Evropske unije - solidarnost treba da se razvija i među državama članicama i među njenim građanima (kroz dalje razvijanje i unapređivanje ideje aktivnog građanstva).
\end{abstract}

Ključne reči: Evropska unija, Kovid 19, kriza, solidarnost, narativ.

\section{Uvod}

U ovom radu istraživaćemo uticaj pandemije Kovid 19 na politike Evropske unije (EU). Pokazaćemo da koncept solidarnosti nije jasno definisan u evropskom pravnom i političkom diskursu, i da se istovremeno određuje i kao princip i kao vrednost, što doprinosi dodatnoj zamagljenosti ovog pojma. Evropska komisija je pokrenula projekat „Novi narativ o Evropi” 2013. godine,

\footnotetext{
${ }^{1}$ Viši naučni saradnik, Institut za evropske studije, Beograd, e-mail: sanja_ivic1@yahoo.com.

${ }^{2}$ Istraživač saradnik, Institut za evropske studije, Beograd, e-mail: rajko.petrovic@ies.rs.
} 
čiji je cilj bio oživljavanje evropskog identiteta i približavanje Evropske unije njenim građanima. ${ }^{3}$ Međutim, ovaj projekat nije bio efikasan jer nije uzeo u obzir pitanje solidarnosti. Krize sa kojima se Evropska unija suočila nakon pokretanja projekta "Novi narativ o Evropi” - migrantska kriza, Bregzit i pandemijska kriza, pokazale su da je neophodno kreiranje novog evropskog narativa zasnovanog na solidarnosti, koji bi doprineo većoj odgovornosti i efikasnosti Evropske unije. Osnovna istraživačka pitanja koja ćemo preispitivati u ovom radu su: uticaj pandemije Kovid 19 na unutarpolitičke odnose u Evropskoj uniji i EU kao globalnog aktera; efikasnost i odgovornost EU u vremenu krize; definisanje pojma solidarnosti u evropskom pravnom i političkom diskursu; analiza postojećeg evropskog narativa i budućnost EU nakon pandemije.

Pandemija Kovid 19 proizvela je veliku krizu u Evropskoj uniji, što je dovelo do preispitivanja fundamentalnih vrednosti na kojima se temelji EU, kao i do preispitivanja ideje evropskog identiteta. Na početku pandemijske krize Evropska unija je pokazala nedostatak solidarnosti. lako su se sve države članice EU suočile sa pandemijom Kovid 19, svaka od njih je imala svoj odgovor, bez ikakve koordinacije. ${ }^{4}$ Evropska unija nije reagovala u skladu sa nadnacionalnim vrednostima i principima na kojima se temelji, određenim članom 2 Ugovora o Evropskoj uniji, a to su poštovanje ljudskog dostojanstva, demokratija, jednakost, sloboda, vladavina prava, kao i poštovanje prava čoveka. ${ }^{5}$ Članom 2 Ugovora o Evropskoj uniji ističe se da su ove vrednosti "zajedničke svim državama članicama u društvu koje karakteriše pluralizam, nediskriminacija, tolerancija, pravda, solidarnost i jednakost...." ${ }^{6}$

Pandemija Kovid 19 ojačala je dihotomiju između nacionalnog i evropskog i ukazala na značaj ranijih rasprava o prirodi evropskog identiteta, budući da je dovela do preispitivanja osnovnih vrednosti na kojima se zasniva Unija. ${ }^{7}$

\footnotetext{
${ }^{3}$ José Manuel Durão Barroso, A New Narrative for Europe (speech), European Commission, Brussels, 2013, Internet: https://ec.europa.eu/commission/presscorner/detail/en/ SPEECH_13_357, 02/04/2021.

${ }^{4}$ Lana Gedošević, Sumrak evropske solidarnosti, Blic, Beograd, 2020, Internet: https://www.blic.rs/vesti/politika/sumrak-evropske-solidarnosti-nije-se-snasla-sporo-jereagovala-i-svima-nametnula-samo/krkee96, 05/04/2020.

5 "Consolidated Version of the Treaty on European Union", European Union, 26 October 2012.

${ }^{6}$ lbid.
} 
„Činjenica da je institucijama EU za brze i krucijalne odluke na početku pandemije, bila potrebna dozvola od država članica, dovoljno govori o EU kao nedovršenom i nefunkcionalnom projektu, jer su ipak neke od najvažnijih ingerencija" ${ }^{8}$ i dalje u nadležnosti država članica. Protivrečnost između nacionalnog i supranacionalnog oduvek je bila svojstvena prirodi Evropske unije, a ova tenzija je vidljivija u periodu kriza. ${ }^{9}$

\section{Kriza evropske solidarnosti}

Od 2009. godine do danas, Evropska unija se suočavala sa ekonomskom, političkom, migracijskom, identitetskom i zdravstvenom krizom. Različite podele unutar Evropske unije, nastale kao posledica ovih kriza, dovele su u pitanje definiciju Evropske unije kao supranacionalne političke zajednice. ${ }^{10}{ }_{\text {,Kriza kao }}$ opšte mesto u diskursu o Evropskoj uniji, čini se da je svoju potpunu, realnu težinu dobila sa izbijanjem pandemije korona virusa (COVID-19), razotkrivši sve slabosti EU - od nespremnosti, nejedinstva, nepostojeće solidarnosti, do neefikasnosti ideje nadnacionalnog projekta a, s druge strane, pojačala je narativ o povratku nacionalnoj državi. Stoga se debate i analize o 'svetu posle korone', u najširem smislu vode na dimenziji globalizam/suverenizam."11

Na samom početku pandemije Evropska unija suočila se sa brojnim unutrašnjim sukobima koji su proizašli iz nedostatka evropske solidarnosti.

\footnotetext{
${ }^{7}$ Bianca Canevari, United in Adversity: On the Importance of European Identity in a PostCoronavirus World, Modern Diplomacy, European Union, 2020, Internet: https://moderndiplomacy.eu/2020/06/22/united-in-adversity-on-the-importance-ofeuropean-identity-in-a-post-coronavirus-world/, 23/03/2021.

${ }^{8}$ Slađana Ćurčić, "Solidarna Unija” - sadašnjost i perspektive, Centar za analizu rizika i upravljanje krizama, Beograd, 2020, Internet: http://www.caruk.rs/solidarna-unijasadasnjost-i-perspektive/, 20/04/2021.

${ }^{9}$ Ruth Wodak, What Future for the EU after COVID-19?, Open Democracy, London, 2020, Internet: https://www.opendemocracy.net/en/pandemic-border/what-future-eu-aftercovid-19/, 03/02/2021.

${ }^{10}$ Sanja Ivić, „Kriza evropskog identiteta” u: Aleksandar Gajić, Milan Igrutinović (urs.), Kriza Evropske unije: Okviri, dometi, trendovi, Institut za evropske studije, Beograd, 2013, str. 211.

${ }^{11}$ Slađana Ćurčić, "Solidarna Unija” - sadašnjost i perspektive, op. cit.
} 
Evropska unija nije reagovala solidarno kada je u pitanju Italija, koja je najviše bila pogođena tokom prvog talasa pandemije, a pokazalo se da ništa nije bilo drugačije ni sa drugim zemljama juga - Španijom i Grčkom. Nedostatak evropske solidarnosti ogledao se i u ograničenjima koje su države članice postavljale na izvoz medicinske opreme u susedne države. ${ }^{12}$

Anketa u devet država članica „Evropske unije pokazala je da postoji rasprostranjeno nezadovoljstvo građana odgovorom Unije na krizu izazvanu korona virusom, ali i snažna saglasnost o potrebi jače evropske saradnje i osećaj da Evropa mora da se osloni na sopstvene snage."13 Anketa agencije Datapraksis (Datapraxis) i JuGov (YouGov), koja je sprovedena tokom poslednje nedelje aprila i prve nedelje maja 2020. godine, i koja je obuhvatala 11.000 građana u devet država članica Evropske unije (Švedskoj, Španiji, Portugalu, Poljskoj, Nemačkoj, Italiji, Francuskoj, Danskoj i Bugarskoj) pokazala je da veliki broj Evropljana (46\%) smatra da Evropska unija nije reagovala odgovorno kada je u pitanju pandemijska kriza. ${ }^{14}$

Najveće nezadovoljstvo izraženo je u Italiji i Francuskoj, pa je tako 63\% građana Italije i $61 \%$ građana Francuske ocenilo da Evropska unija nije bila dorasla ozbiljnosti situacije i nije reagovala odgovorno. Najpozitivnije mišljenje, sa tek $36 \%$ podrške, zabeleženo je u Portugalu. ${ }^{15}$ Nezadovoljstvo nedostatkom zajedničkog evropskog odgovora na pandemijsku krizu, izrazilo je 58\% građana Francuske i 52\% građana Portugala, kao i većina ispitanih građana ostalih država članica EU. ${ }^{16}$ Da je pandemijska kriza pokazala da je Uniji neophodna jača unutrašnja saradnja složila se većina ispitanika, a posebno u Portugalu (90\%), Španiji (81\%) i Italiji (77\%). ${ }^{17}$ Predsednica Evropske komisije, Ursula fon der Lajen

\footnotetext{
${ }^{12}$ Richard Gray, Lack of Solidarity Hampered Europe's Coronavirus Response, Research Finds, Horizon: The EU Research and Innovation Magazine, Brussels, 2020, Internet: https://horizon-magazine.eu/article/lack-solidarity-hampered-europe-s-coronavirusresponse-research-finds.html, 28/03/2021.

${ }^{13}$ Beta, Evropljani nezadovoljni odgovorom EU na pandemiju, ipak žele jaču saradnju, Danas, Beograd, 2020, Internet: https://www.danas.rs/svet/evropljani-nezadovoljniodgovorom-eu-na-pandemiju-ipak-zele-jacu-saradnju/, 10/03/2021.

${ }^{14}$ Ibid.

${ }^{15}$ Sarah Lawton, Europeans Disillusioned with EU Coronavirus Response, New Poll Finds, EurActiv, Brussels, 2020, Internet: https://www.euractiv.com/section/politics/news/ europeans-disillusioned-with-eu-coronavirus-response-new-poll-finds/, 20/05/2021.

${ }^{16} \mathrm{lbid}$.
} 
(Ursula von der Leyen), u govoru u Evropskom parlamentu, 26. marta 2020. godine, kritikovala je nedostatak solidarnosti između država članica EU u vreme izbijanja pandemije Kovid 19 i pozvala države članice EU da pokažu solidarnost. ${ }^{18}$

Pandemijska kriza samo je potcrtala postojeće podele unutar Evropske unije. ${ }^{19}$ Italija, Francuska, Španija, i šest drugih država članica EU, zatražile su od Evropske unije „da podele teret evropskog duga, nazvanog koronabonds, kako bi se pomoglo u borbi protiv virusa". ${ }^{20}$ Ipak, ostale članice EU, predvođene Holandijom i Nemačkom, pružile su otpor ovoj ideji. Dakle, pandemijska kriza proizvela je unutrašnje binarne opozicije unutar Evropske unije, uzimajući u obzir podelu između južnih država članica (Italija i Španija, uključujući Francusku) i severnih država članica (predvođenih Holandijom, uključujući Nemačku). ${ }^{21}$ Južne države članice EU naglasile su važnost zajedničkog, „evropskog odgovora” na pandemijsku krizu, a ne samo odgovora na nacionalnom nivou. ${ }^{22}$ Serđo Fabrini (Sergio Fabbrini) ističe da ova podela ukazuje i na različite vizije Evrope. ${ }^{23}$

Zbog nedostatka evropske solidarnosti, bivši ministar unutrašnjih poslova i lider partije desnog centra „Liga”, Mateo Salvini (Matteo Salvini), najavio je mogućnost da Italija razmotri pitanje napuštanja Evropske unije. ${ }^{24}$ Predsednica Evropske komisije, Ursula fon der Lajen, uputila je izvinjenje Italiji u ime

${ }^{17} \mathrm{lbid}$.

${ }^{18}$ Beatriz Rios, Commission Chief, MEPs Slam Lack of EU Solidarity in COVID-19 Crisis, EurActiv, Brussels, 2020, Internet: https://www.euractiv.com/section/coronavirus/news/ commission-chief-meps-slam-lack-of-eu-solidarity-in-covid19-crisis/, 24/04/2021.

${ }^{19}$ Françoise Michel and Dave Clark, Epidemic Infects Europe with "Germ of Division", The Jakarta Post, Jakarta, 2020, Internet: https://www.thejakartapost.com/news/2020/ 03/30/epidemic-infects-europe-with-germ-of-division.html, 05/03/2021.

${ }^{20}$ Blic, Španija i Italija očajnički mole Brisel, Beograd, 2020, Internet: https://www.blic.rs/ vesti/svet/spanija-i-italija-ocajnicki-mole-briselevropo-upomoc/7rttlcq, 20/03/2021.

${ }^{21}$ Sergio Fabbrini, The Future of Europe is Being Decided Now, Social Europe, European Union, 2020, Internet: https://www.socialeurope.eu/the-future-of-europe-is-beingdecided-now, 22/04/2021.

22 Ibid.

${ }^{23} \mathrm{lbid}$.

${ }^{24}$ Ciaran McGrath, Furious Italy Tells EU 'Change the Rules of We'll do the Same as the British', Express, London, 2020, Internet: https://www.express.co.uk/news/world/12434 57/brexit-boost-italy-matteo-salvini-boris-johnson-italexit-eu-brussels, 08/04/2021. 
Evropske unije, ocenivši da Evropska unija nije pružila blagovremenu pomoć Italiji na početku pandemije, kada je Italiji pomoć bila najpotrebnija. ${ }^{25}$ Evropska unija je naknadno postigla sporazum o koordinaciji između država članica i zajedničkoj nabavci medicinske opreme. EU je izdvojila sredstva za razvoj vakcine protiv korona virusa, a donacijama je pomogla i zemljama Zapadnog Balkana. ${ }^{26}$ Ipak, pandemijska kriza je pokazala je da Evropska unija prvo traži odgovore na nacionalnom, pa tek onda na nadnacionalnom, evropskom, nivou.

Pandemijska kriza je značajno uticala i na poziciju Evropske unije kao globalnog aktera. Pored zdravstvenog, ova kriza je nesumnjivo postala i važno geopolitičko pitanje, budući da se globalni akteri nadmeću u proizvodnji, nabavci i distribuciji vakcina protiv virusa. Zemlje koje su uspele da proizvedu vakcinu uvećale su svoj geopolitički i diplomatski uticaj. Trenutno je u upotrebi pet vakcina protiv korona virusa - američka „Fajzer/Biontek”, američka „Moderna”, britanska „Oksford/AstraZeneka”, kineska "Sinofarm” i ruska "Sputnjik V” vakcina. Postoje i kineska „Sinovak" i indijska „,Kovaksin” vakcina, ali su one u daleko manjoj upotrebi. Dakle, ovo nam pokazuje da su globalni akteri u tom smislu Sjedinjene Američke Države, Rusija, Kina i Velika Britanija. Od država članica EU, jedino Nemačka učestvuje u proizvodnji „,Fajzer/Biontek” vakcine, ali nema sopstvenu vakcinu.

Pojava novih sojeva korona virusa, poput britanskog, južnoafričkog i brazilskog dodatno komplikuje borbu za nabavku vakcina. Kao što je prethodno navedeno, EU se suočila sa problemima već na početku ove krize, a Italija je dobila značajnu pomoć od Kine, ali i od Rusije i Kube, čime su mnogi zvaničnici EU izrazili nezadovoljstvo. ${ }^{27}$ "Zdravstveni put svile” kojim je Kina ojačala svoj ekonomski i diplomatski prodor ka Evropi naišao je na pozitivne reakcije zemalja Balkana, Centralne i Istočne Evrope, ali i na negativne reakcije iz vrha Evropske unije. lako je kasnije Evropska unija dostavila značajnu pomoć ugroženim zemljama, to je ostalo u senci kineske i ruske pomoći zemljama

\footnotetext{
25 Joanna Gill, EU Commission President Offers 'Heartfelt Apology' to Italy, as MEPs Debate Coronavirus Response, Euronews, Brussels, 2020, Internet: https://www.euronews.com/ 2020/04/16/eu-commission-president-offers-heartfelt-apology-to-italy, 18/03/2021.

${ }^{26}$ Lana Gedošević, Sumrak evropske solidarnosti, op. cit.

${ }^{27}$ Kristof Haselbah, Kineska i ruska korona-diplomatija, Deutsche Welle, Bon, 2021, Internet: https://www.dw.com/sr/kineska-i-ruska-korona-diplomatija/a-56507939, 09/02/2021.
} 
poput Srbije, ali i zahteva zemalja poput Mađarske i Slovačke za nabavku kineske, odnosno ruske vakcine protivno zvaničnoj politici Brisela, čime su Peking i Moskva stekli važne geopolitičke poene. ${ }^{28}$

Evropska agencija za lekove (EMA) za sada je odobrila upotrebu „,Fajzer/Biontek" $\mathrm{i}$ „,Moderna” vakcine. Evropska unija je planirala da do kraja leta 2021. godine vakciniše oko 70\% svog odraslog stanovništva. ${ }^{29}$ Ipak, do februara 2021. godine, vakcinisano je tek 12 miliona stanovnika EU (oko 2\%). ${ }^{30}$ Problem predstavlja to što je zvanični Brisel „Fajzer" vakcine naručio tek jesenas, a „Moderna” vakcine čak i kasnije. Za razliku od Evropske unije, kada je krajem januara 2021. kompanija „Novavaks” saopštila da ima pouzadnu vakcinu protiv korona virusa, London je odmah naručio 60 miliona doza. ${ }^{31}$ Dodatni problem za EU pojavio se kada je američki predsednik, Džo Bajden (Joe Biden), nastavio sa politikom da se bitne supstance i elementi za proizvodnu vakcine ne izvoze izvan SAD, što je stvorilo problem u saradnji između američkog proizvođača „Fajzera” i nemačke „Biontek” laboratorije. Predsednik SAD, Bajden, planira da u prvih 100 dana vlasti vakciniše 100 miliona Amerikanaca i za njegovu administraciju, bar kada je reč o pandemijskoj krizi, EU ostaje trećerazredni partner. ${ }^{32}$

Za nemačkog ministra zdravlja Jensa Špana (Jens Spahn) nema sumnje da Rusija i Kina koriste vakcine za vođenje sopstvene geopolitike. ${ }^{33}$ Ove zemlje dostavile su svoje vakcine ne samo Srbiji, već i Mađarskoj, koja je jedna od država članica EU, što je izazvalo dodatni razdor unutar same Unije. Špan smatra da EU ne sme da napravi grešku kao tokom finansijske krize 2009. godine, kada je dozvolila Moskvi i Pekingu da prošire svoj uticaj, poput kineske

\footnotetext{
${ }^{28}$ Michael Leigh, Vaccine Diplomacy: Soft Power Lessons from China and Russia?, Bruegel, Brussels, 2021, Internet: https://www.bruegel.org/2021/04/vaccine-diplomacy-softpower-lessons-from-china-and-russia/, 20/05/2021.

${ }^{29}$ Radio Slobodna Evropa, Spora vakcinacija u EU najavljuje sumornu godinu, Sarajevo, 2021, Internet: https://www.slobodnaevropa.org/a/spora-vakcinacija-u-eu-najavljujesumornu-godinu/31055916.html, 20/05/2021.

${ }^{30}$ Kristof Haselbah, Kineska i ruska korona-diplomatija, op. cit.

${ }^{31}$ Nick Tiggle, Novavax: Deal agreed to 'fill and finish' 60 million doses in UK, BBC, London, 2021, Internet: https://www.bbc.com/news/uk-england-tees-56570168, 20/05/2021.

32 lbid.

${ }^{33}$ Kristof Haselbah, Kineska i ruska korona-diplomatija, op. cit.
} 
kupovine grčke luke Pirej, te da je borba protiv korona virusa za EU ne samo humanitarno, već i geostrateško pitanje. ${ }^{34}$

Zbog veoma nepovoljne epidemiološke situacija u Evropskoj uniji, predsednica Evropske komisije, Ursula fon der Lajen, obznanila je da je Brisel otvoren za izdavanje dozvole za kineske i ruske vakcine na svojoj teritoriji, uz uslov da se one temeljno preispitaju. ${ }^{35}$ Novinar „Dojče velea”, Kristof Haselbah (Christoph Hasselbach), ističe da bi to pomoglo rešavanju postojećih zdravstvenih izazova, ali bi, isto tako, to bilo i priznavanje sopstvene slabosti EU. ${ }^{36}$ Nemačka kancelarka Angela Merkel (Angela Merkel) takođe je izjavila da podržava nabavku ruske vakcine, pod uslovom da je odobri EMA. ${ }^{37}$ Tim putem je, kada je reč o državama članicama EU, prva krenula Mađarska, koja je još u februaru 2021. godine dobila i prvu pošiljku kineskih vakcina. Premijer Mađarske, Viktor Orban (Viktor Orbán), kritikovao je EU da reaguje presporo u nabavci vakcina, pa je Mađarska po hitnom postupku odobrila ruske i kineske vakcine. ${ }^{38}$ Interes za ruskom vakcinom pokazale su i Češka, Slovačka i Poljska. ${ }^{39}$ Da je Brisel sve više spreman na to da i zvanično započne nabavku ruskih vakcina govori izjava evropskog komesara za unutrašnje tržište Tjerija Bretona (Thierry Breton), koji je istakao da je prihvatljivo to što neke članice EU žele da nabave rusku i kinesku vakcinu protiv korona virusa. ${ }^{40}$

U svakom slučaju, nakon pandemije i Evropska unija i svet će se suočiti sa geopolitičkim, ekonomskim, bezbednosnim, ekološkim i promenama vrednosnih sistema. ${ }^{41}$ Pomenuto istraživanje "Datapraksisa" i "JuGova” pokazalo je da se Evropljani zalažu za čvršću saradnju između evropskih

\footnotetext{
${ }^{34} \mathrm{lbid}$.

${ }^{35} \mathrm{lbid}$.

${ }^{36}$ Ibid.

${ }^{37}$ Bernd Rigert, Zbog mutacija virusa EU prilagođava strategiju vakcinacije, Deutsche Welle, Brisel, 2021, Internet: https://www.dw.com/sr/zbog-mutacija-virusa-euprilagođava-strategiju-vakcinacije/a-56604865, 20/05/2021.

38 Ibid.

${ }^{39} \mathrm{Al}$ Jazeera Balkans, Evropski komesar: U redu je nabavka kineskih i ruskih vakcina, Sarajevo, 2021, Internet: https://balkans.aljazeera.net/news/world/2021/3/5/bretonu-redu-je-da-clanice-eu-a-nabave-kineske-i-ruske-vakcine, 20/05/2021.

40 lbid.

${ }^{41}$ Slađana Ćurčić, „Solidarna Unija” - sadašnjost i perspektive“, op. cit.
} 
zemalja, jer osećaju da su tokom pandemijske krize prepušteni sami sebi. ${ }^{42}$ „Egzistencijalna kriza Evropske unije postoji već neko vreme, međutim pandemija je već postojeće teškoće dodatno istakla. (...) Ideja 'Evropljanina' ostala je apstraktna, jer je udaljena od samih građana, usled nepostojanja osećaja autentičnog jedinstva i pripadnosti 'zajednici evropskih naroda'. Otuda, njihovo poimanje o sebi i drugima ostaje u nacionalnim okvirima, a umesto federalne države na delu je sve više savez država koje slede sopstvene nacionalne interese, a ne zamišljene evropske interese." ${ }^{43}$ Evropska unija se suočava ne samo sa pandemijskom krizom, već i sa krizom identiteta. ${ }^{44}$

\section{Kriza evropskog identiteta}

Ideja o evropskom identitetu, koju su ustanovili šefovi vlada devet država članica Evropske zajednice ${ }^{45}$ Deklaracijom o evropskom identitetu 1973. godine, zasnivala se na principu jedinstva ovih vlada spram njihovih novih odgovornosti prema ostatku sveta. ${ }^{46}$ Stoga je pojam evropskog identiteta nastao kao sredstvo konsolidovanja pozicije Evrope u okviru svetskog poretka. ${ }^{47}$ Deklaracijom o evropskom identitetu ističe se distinktivan karakter evropskog identiteta, jedinstvo Evropske zajednice i njena odgovornost prema ostatku sveta, koja je obuhvatala: 1. odgovornost prema drugim evropskim državama i narodima; 2. odgovornost prema zemljama Mediterana, Afrike i Srednjeg istoka; 3. razvijanje odnosa Sjedinjenih Američkih Država i Evrope zasnovanog na temeljima jednakosti i ,duhu prijateljstva“;48 4. saradnju i

\footnotetext{
${ }^{42}$ Sarah Lawton, Europeans Disillusioned with EU Coronavirus Response, New Poll Finds, op. cit.

${ }^{43}$ Slađana Ćurčić, "Solidarna Unija” - sadašnjost i perspektive, op. cit.

${ }^{44}$ Ruth Wodak, What Future for the EU after COVID-19?, op. cit.

45 Šest osnivačkih zemalja Evropskih zajednica bile su: Zapadna Nemačka, Francuska, Holandija, Belgija, Italija i Luksemburg. Do prvog proširenja Evropske zajednice (na devet članica) došlo je 1. januara 1973. godine, pristupanjem Velike Britanije, Irske i Danske.

46 "Declaration on European Identity", European Communities, 14 December 1973.

${ }^{47}$ Bo Stråth, "A European Identity to the Historical Limits of a Concept", European Journal of Social Theory, vol. 5, no. 4, 2002, p. 389.

48 "Declaration on European Identity", op. cit., p. 4.
} 
konstruktivan dijalog sa Japanom i Kanadom; 5. saradnju sa Sovjetskim Savezom i zemljama Istočne Evrope. ${ }^{49}$

U ovim raspravama o evropskom identitetu ističe se koherentnost Evrope kao aktera na polju svetske politike. Ovakav pristup, kojim se postavlja oštra distinkcija između evropskog i neevropskog, a evropski identitet poistovećuje sa homogenim skupom principa (poput demokratije, vladavine prava, socijalne pravde i poštovanja ljudskih prava ${ }^{50}$ ), kao i vrednosti poput evropskog kulturnog nasleđa, ${ }^{51}$ zasnovan je na binarnim opozicijama ${ }^{52}$ okrenutim ka spolja. Dakle, konstitutivni činioci evropskog identiteta bili su spoljašnji, geografski i kulturološki ustanovljeni drugi, poput Rusije, Turske i zemalja Istočne Evrope.

Izgradnja kolektivnog evropskog identiteta dobila je novi pravac nakon 2009. godine, što su pokazale dužnička kriza u evrozoni, migrantska kriza, rezultati referenduma o Bregzitu, kao i pandemijska kriza. Ovaj novi pravac doveo je do preosmišljavanja konstitutivnih činilaca evropskog identiteta. Binarne hijerarhije označavaju nejednake odnose moći unutar EU. Kao što je već navedeno, od nastanka ideje o zajedničkom, evropskom identitetu sedamdesetih godina XX veka do 2009. godine, one su uglavnom bile okrenute ka spolja, razdvajajući evropsko i neevropsko, dok nakon 2009. godine, dolazi do velike promene prvenstveno proizvedene dužničkom krizom u evrozoni i migrantskom krizom, što je dovelo do podela unutar same Evropske unije.

Dužnička kriza u evrozoni ukazala je na veliki nedostatak evropske solidarnosti. , lako se grčko nasleđe, između ostalog, navodilo kao civilizacijska osnova evropskog identiteta i evropskih vrednosti, u jeku grčke dužničke krize, evropska budućnost Grčke i ostalih zemalja članica EU zahvaćenih dužničkom krizom, dovođena je u pitanje od strane predstavnika političke elite EU."53

\footnotetext{
${ }^{49}$ lbid.

${ }^{50}$ Ibid., p. 2

51 Ibid.

52 Koncept binarnih opozicija potiče od strukturalizma i poststrukturalizma. Filozofi poststrukturalizma tvrde da unutar binarne opozicije jedna od dve suprotnosti preuzima ulogu dominacije nad drugom.

${ }^{53}$ Beyza Tekin, Re-negotiating European Identity at Times of Crisis, Euroacademia, Paris, 2012, Internet: https://euroacademia.eu/wordpress/wp-content/uploads/2012/04/ Beyza_Tekin_Re_Negotiating_European_Identity_In_Times_of_Crisis1.pdf, 23/04/2021.
} 
Od početka dužničke krize u evrozoni vidljiva je podvojenost država članica EU čije su ekonomije uspešnije i onih koje su identifikovane kao problematične po pitanju otplate javnog duga. ${ }^{54}$ Kao takve, prvenstveno su identifikovane Grčka, Portugal, Španija, Italija i Irska. „Sa dužničkom krizom u evrozoni primetan je zaokret ka konstruisanju hijerarhija i odnosa moći unutar same Evropske unije (na primer, centar/periferija, ekonomski stabilni sever/nestabilni jug; odgovorne države članice EU/neodgovorne članice EU itd.). ${ }^{55}$ "Ovo je novi proces u okviru kojeg konstitutivni činioci evropskog identiteta više nisu samo spoljašnji, geografski i kulturološki ustanovljeni 'drugi' poput Turske i Rusije, već su to i unutarnji entiteti, same članice EU."56 Ovaj proces razbija homogenost Evropske unije što se vrlo jasno videlo i u Bregzitu koji je pokazao fragilnost evropskog identiteta.

Migrantska kriza u Evropi, koja je eskalirala tokom 2015. godine, takođe je reflektovala krizu evropske solidarnosti. Evropska unija nije kreirala sistem koji bi omogućio da države članice na pravičan način podele odgovornost za prihvatanje migranata. Kao posledica, nastale su brojne nesuglasice država članica oko toga koje od njih treba da ugoste azilante i migrante koji stignu do evropskih obala. Predsednik Francuske, Emanuel Makron (Emmanuel Macron), i premijer Grčke, Kirijakos Micotakis (Kyriakos Mitsotakis), dogovorili su se 22. avgusta 2019. godine u Parizu da zatraže veću solidarnost u Evropskoj uniji i pronađu evropsko rešenje za migrantsku krizu. Micotakis je istakao „, da teret migrantske krize ne smeju da nose jedino zemlje koje su najviše izložene prilivu migranata kao što su Grčka, Italija i Španija." ${ }^{57}$ Predsednik Francuske, Emanuel Makron, implicitno je kritikovao bivšeg ministra unutrašnjih poslova Italije, Matea Salvinija, koji je odbio da „dozvoli iskrcavanje migranata sa spasilačkih brodova u italijanskim lukama. (...) Predsednik Francuske je rekao da su

\footnotetext{
${ }^{54}$ Ivan Vujačić, "Evropska unija - transformacija ili raspad" u: Mihail Arandarenko, Ivan Vujačić (urs.), Evropska unija i Srbija: Od tranzicije do pridruživanja, Ekonomski fakultet, Beograd, 2012, str. 16.

${ }^{55}$ Sanja Ivić, „Kriza evropskog identiteta”, op. cit., str. 211.

${ }^{56}$ Ibid., str. 211.

57 Danas, Francuska i Grčka traže veću solidarnost EU povodom migrantske krize, Beograd, 2019, Internet: https://www.danas.rs/svet/francuska-i-grcka-traze-vecu-solidarnost-eupovodom-migrantske-krize/, 15/05/2021.
} 
'neprihvatljive odluke ponovo donete' i dodao da države 'moraju da pronađu evropsko rešenje'." 58

Dakle, binarne opozicije na kojima se temelji evropski identitet, posebno su vidljive u vremenu kriza. Pandemijska kriza, kojoj su prethodile migracijska i ekonomska kriza EU, pokazale su se kao izazov evropskom identitetu, budući da su produbile podele unutar Unije i ojačale binarne opozicije kao što su: nacionalno/evropsko, građanin/stranac, unutarnje/spoljno itd. Ove binarne opzicije ukazuju na nedostatak evropske solidarnosti, iako je solidarnost jedan od temeljnih principa Unije. Kao što je istakao bivši predsednik Evropske komisije Žan-Klod Junker (Jean-Claude Juncker), ,,reč solidarnost pojavljuje se šesnaest puta u ugovorima sa kojima su se složile i ratifikovale sve države članice Evropske unije". ${ }^{59}$

Ugovor iz Rima se indirektno odnosi na solidarnost, za šta se zalaže i Ugovor iz Mastrihta.$^{60} \mathrm{U}$ paragrafu 6 preambule Ugovora o Evropskoj uniji istaknuta je težnja da zemlje članice Unije prodube solidarnost između njihovih naroda. ${ }^{61} \mathrm{U}$ članu 2 Ugovora o Evropskoj uniji, solidarnost je označena kao jedna od temeljnih vrednosti pluralističkog društva. ${ }^{62} \mathrm{U}$ paragrafu 2 člana 24 Ugovora tvrdi se da će se zajednička spoljna i bezbednosna politika razvijati na principu solidarnosti među državama članicama. ${ }^{63}$ Uprkos tome što je princip solidarnosti utkan u najvažniji evropski pravni akt, ne postoji jasna definicija solidarnosti i različiti subjekti je u političke ili druge svrhe tretiraju na različite načine. ${ }^{64}$

Član 3(3) Ugovora o Evropskoj uniji navodi da će Evropska unija promovisati „ekonomsku, socijalnu i teritorijalnu koheziju i solidarnost između država članica". 65 Međutim, nije jasno da li ovaj koncept predstavlja princip ili vrednost.

\footnotetext{
$58 \mathrm{lbid}$

59 Jean-Claude Juncker, State of the Union 2016: Towards a Better Europe-A Europe that Protects, Empowers and Defends, European Commission, Strasbourg, 2016, Internet: https://ec.europa.eu, 13/05/2021/.

${ }^{60}$ Andrew T. Williams, "Taking Values Seriously: Towards a Philosophy of EU Law", Oxford Journal of Legal Studies, vol. 20, no. 3, 2009, p. 553.

61 "Consolidated Version of the Treaty on European Union", op. cit.

62 Ibid.

63 Ibid.

${ }^{64}$ Heribert Franz Koeck, "Solidarity in the European Union", Albolafia: Revista de Humanidades y Cultura, no. 16, February 2019, p. 86.

65 "Consolidated Version of the Treaty on European Union", op. cit.
} 
Endrju Vilijams (Andrew Williams) naglašava da je ova razlika značajna, budući da je priroda vrednosti teleološka - one „preporučuju“, dok je priroda principa deontološka - jer oni „zapovedaju“. ${ }^{66} \mathrm{U}$ preambuli Povelje o osnovnim pravima Evropske unije, postavlja se distinkcija između vrednosti i principa, i solidarnost se definiše kao vrednost. ${ }^{67}$ Međutim, član 21 Ugovora o Evropskoj uniji definiše solidarnost kao princip, dok ga član 2 definiše kao vrednost. ${ }^{68}$ Dakle, ne postoji jasno određenje evropske solidarnosti.

Na primerima ekonomske, migracijske, kao i pandemijske krize, pokazalo se da države članice Evropske unije polaze od rešenja i interesa na nacionalnom nivou, pa tek onda traže zajedničke, evropske odgovore. ${ }^{69}$ Rut Vodak (Ruth Wodak) ističe da su mnogi građani Evropske unije tek tokom pandemijske krize shvatili da je pitanje zdravlja prvenstveno pitanje nacionalnih (a ne evropskih) politika. ${ }^{70}$ Isto se može tvrditi i za pitanja migracija i prava na azil.

„Haotični, zakasneli, nekoordinisan odgovor sa vrha EU, samo je deo šire institucionalne krize Unije, oličene u nefunkcionalnosti briselske birokratije, prenormiranosti sistema, demokratskom deficitu i stoga, već neko vreme aktuelnom diskursu o potrebi unutrašnje reforme EU. Pokušaj sprovođenja institucionalnih reformi, zarad čvršćeg povezivanja i vraćanja izgubljenog kredibiliteta, teško da bi mogao da nadvlada surovu istinu sa kojom su suočene

\footnotetext{
${ }^{66}$ Andrew T. Williams, "Taking Values Seriously: Towards a Philosophy of EU Law", op. cit., p. 559.

67 „Svesna svoje duhovne i moralne baštine, Unija se temelji na nedeljivim univerzalnim vrednostima ljudskog dostojanstva, slobode, jednakosti i solidarnosti; temelji se na principima demokratije i vladavini prava. Ona stavlja pojednica u centar svojih aktivnosti ustanovljavanjem državljanstva Unije i stvaranjem jednog područja slobode, bezbednosti i pravde. Unija doprinosi očuvanju i razvoju tih zajedničkih vrednosti, poštujući pritom raznolikost kultura i tradicija naroda Evrope kao i nacionalne identitete država članica i organizaciju njihovih javnih vlasti na nacionalnim, regionalnim i lokalnim nivoima; ona podstiče izbalansiran i održiv razvoj i obezbeđuje slobodno kretanje ljudi, dobara, usluga i kapitala i slobodu preduzetništva (...) Ova Povelja reafirmiše, poštujući ovlašćenja i zadatke Zajednice i Unije i princip supsidijarnosti, prava koja proističu, naročito iz ustavnih tradicija i međunarodnih obaveza koje su zajedničke za države članice." ("Povelja o osnovnim pravima Evropske unije", Nica, 17. decembar 2000.).

68 "Consolidated Version of the Treaty on European Union", op. cit.

${ }^{69}$ Lana Gedošević, Sumrak evropske solidarnosti, op. cit.

70 Ruth Wodak, What Future for the EU after COVID-19?, op. cit.
} 
najteže pogođene članice - da se u ozbiljnoj krizi mogu osloniti isključivo na sopstvene zdravstvene sisteme i ekonomske kapacitete i eventualno pomoć van Unije." ${ }^{\prime 1}$ Stoga je neophodno kreiranje novog evropskog narativa zasnovanog na solidarnosti.

\section{Budućnost Evropske unije nakon pandemijske krize: značaj razvijanja ideje transnacionalne solidarnosti}

Pandemijska kriza ne predstavlja samo izazov za Evropsku uniju, već i mogućnost za njen dalji razvoj. Na iskustvu proisteklom iz pandemijske krize, kao i ostalih kriza sa kojima se suočila, Unija ima mogućnost da redefiniše narative na kojima se do sada zasnivala. Kao što ističe Vinsent Dela Sala (Vincent Della Sala), svaki oblik društvene organizacije zahteva narative koji određuju njegov smisao i značenje, kao i razlog njegovog postojanja. ${ }^{72}$ Pol Riker smatra da je celokupno ljudsko iskustvo narativnog karaktera. ${ }^{73}$

Kako bi se suočila sa brojnim krizama, Evropska unija je pokrenula projekat stvaranja novog narativa koji bi doveo do ojačavanja vrednosti na kojima se zasniva Unija, ukazao na smisao njenog postojanja i značaj EU kao supranacionalne političke zajednice, kako ne bi preovladali populistički i nacionalistički narativi, koji su počeli da jačaju u Evropskoj uniji. ${ }^{74}$ Evropska komisija osmislila je projekat „Novi narativ o Evropi” 2013. godine, čiji je cilj bio oživljavanje evropskog identiteta i približavanje Evropske unije njenim građanima. Tadašnji predsednik Evropske Komisije, Žoze Manuel Barozo (José Manuel Barroso), istakao je da porast populizma i ekstremnog nacionalizma predstavlja pretnju evropskoj budućnosti. ${ }^{75}$ On je, takođe, istakao da se

\footnotetext{
71 lbid.

72 Vincent Della Sala, "Political Myth, Mythology and the European Union", Journal of Common Market Studies, vol. 48, no. 1, 2010, p. 1.

${ }^{73}$ Pol Riker, Vreme i priča, tom 1, Izdavačka knjižarnica Zorana Stojanovića, Sremski Karlovci, 1993.

74 José Manuel Durão Barroso, State of the Union 2012 Address, European Parliament, Strasbourg, 2012, Internet: https://ec.europa.eu/commission/presscorner/detail/en/ SPEECH_12_596, 28/03/2021.

75 José Manuel Durão Barroso, A New Narrative for Europe, op. cit.
} 
Evropska unija nalazi u finansijskoj, ekonomskoj, socijalnoj i političkoj krizi, koje izazivaju nepoverenje kod njenih građana ${ }^{76}$, pa je stoga neophodno kreiranje novog evropskog narativa. Barozo je naglasio i da je neophodno osloboditi se iluzije da se na probleme sa kojima se suočava Evropska unija može odgovoriti rešenjima na nivou država članica. ${ }^{77}$

Projekat „Novi narativ o Evropi” naglašavao je značaj evropske kulture u najširem smislu (uključujući i nauku). Bivši predsednik Evropske komisije, Barozo, pozvao je umetnike i intelektualce da učestvuju u kreiranju „novog narativa o Evropi”. Cilj ovog projekta bio je da se ukaže da priroda Evropske unije nije samo ekonomska. ${ }^{78}$ Projekat je težio i podsticanju kritičke diskusije o evropskim vrednostima među mladima.

Bez obzira na nedostatak evropske solidarnosti, što je primetno još od dužničke krize u evrozoni, u okviru novog evropskog narativa zanemaruje se značaj razvijanja evropske solidarnosti. lako je tadašnji predsednik Evropske komisije, Barozo, u svom govoru održanom u Evropskom parlamentu 2012. godine ${ }^{79}$ naglasio značaj razvijanja evropske solidarnosti i zajedničke odgovornosti država članica, novi evropski narativ nije se zasnivao na pojmu solidarnosti, već na ideji zajedničke evropske kulture i evropskih vrednosti. S druge strane, Evropska komisija je naglasila da „Novi narativ o Evropi”, zasnovan na isticanju zajedničke kulture, može da doprinese i jačanju solidarnosti. U saopštenju koje je Evropska komisija objavila 10. jula 2013. godine, istaknuto je da je svrha ovog projekta razvijanje „vizije o Evropi, koja se može prilagoditi trenutnim izazovima poput solidarnosti, jačanja demokratskog legitimiteta EU i kreiranja uloge EU kao globalnog aktera." ${ }^{80}$

Budući da se i nakon ove inicijative kreiranja novog evropskog narativa, čija je svrha bila suočavanje Evropske unije sa porastom populizma, nepoverenjem njenih građana, kao i socijalnom i ekonomskom krizom, Evropska unija suočila sa novim izazovima poput Bregzita, migrantske krize i pandemijske krize, i da

\footnotetext{
${ }^{76}$ José Manuel Durão Barroso, State of the Union 2012 Address, op. cit.

77 José Manuel Durão Barroso, A New Narrative for Europe, op. cit.

78 Ibid.

79 José Manuel Durão Barroso, State of the Union 2012 Address, op. cit.

${ }^{80}$ European Commission, New Narrative for Europe: General Assembly Launched in Warsaw, Press Release, Brussels, 2013, Internet: https://ec.europa.eu/commission/ presscorner/detail/en/IP_13_676, 16/05/2021.
} 
nije došlo do ojačavanja evropskog identiteta i solidarnosti, niti do rešavanja problema demokratskog deficita, može se zaključiti da je ovaj projekat bio neuspešan. Projekat Novi narativ o Evropi ,izgleda kao još jedan pokušaj da se oživi iluzija da su Evropljani podržali evropski projekat zbog zajedničke kulture." ${ }^{\prime 1}$ Kao što ističe Mišel Privo (Michael Privot), „,pokušaj oslanjanja na podršku umetnika i intelektualaca kao modela transnacionalizma i antipopulizma, nadajući se da će oni moći da ožive umirući žar proevropskih osećanja među Evropljanima je iluzija. Time se, u stvari, značaj kulture, umetnika i intelektualaca svodi na ulogu dimne zavese, koja skriva osnovne uzroke nezadovoljstva Evropljana", koji se ogledaju u velikom jazu u preraspodeli resursa, socijalnoj ekskluziji, demokratskom deficitu, nedostatku evropske solidarnosti i tako dalje.

Stoga je neophodno kreiranje novog evropskog narativa zasnovanog na ideji transnacionalne solidarnosti, "kako bi EU poboljšala svoju relevantnost, legitimitet i otpornost. Solidarnost država članica i institucionalni dizajn EU do sada su se pokazali slabima u pružanju značajnih socijalnih mera ili u razradi evropskog građanstva nezavisno od paradigmi povezanih sa tržištem. Svaki održivi transformativni korak zahteva ponovno fokusiranje na 'horizontalnu' solidarnost među građanima. (...) To zahteva preoblikovanje odnosa između političkih i pravnih narativa. Pravna paradigma je do sada favorizovala narative koji su davali prioret pravima koje donosi građanstvo EU nad solidarnošću kao principom ili standardom." ${ }^{\prime 2}$

Evropska unija je postmoderna, postnacionalna, post-vestfalska višeslojna politička zajednica, budući da prevazilazi granice nacionalnog. ${ }^{83}$ Međutim, javni diskurs koji se odnosi na solidarnost, kao literatura u okviru koje se proučava ovaj pojam, i dalje su uglavnom ograničeni na ideju solidarnosti iz ugla nacionalne države. ${ }^{84}$ Složeni sistem poput Evropske unije se ne uklapa u ovaj

${ }^{81}$ Michael Privot, A New Narrative for Europe: From Myth to Mythomania, EurActiv, Brussels, 2014, Internet: https://www.euractiv.com/section/eu-elections-2014/opinion/ a-new-narrative-for-europe-from-myth-to-mythomania/, 4/05/2021.

${ }^{82}$ Malcolm Ross, "Transnational Solidarity: A Transformative Narrative for the EU and its Citizens?", Acta Politica, vol. 56, no. 3, 2021, p. 220.

${ }^{83}$ Vincent Della Sala, "Political Myth, Mythology and the European Union", op. cit., p. 1.

${ }^{84}$ Ivan Milovanović, "The Experience of COVID-19 Pandemic and Solidarity in the European Union", in: Ivan Stanojević (ed), Political Consequences of the Pandemic, The Serbian Political Science Association, Belgrade, 2021, p. 163. 
pojam solidarnosti, i potrebno je razvijanje narativa zasnovanog na transnacionalnom pojmu solidarnosti. ${ }^{85}$ Za razliku od pojma solidarnosti koji se odnosi na nacionalne države, razvijanje ideje evropske solidarnosti treba da obuhvati višeslojnu, nadnacionalnu prirodu EU i solidarnost treba da se razvija i među državama članicama, i među njenim građanima. ${ }^{86}$

Za razvoj transnacionalne solidarnosti posebno je značajno razvijanje aktivnog građanstva, i angažovanje građana Evropske unije u podršci pravima građana u drugim državama članicama EU. „Pojam aktivno građanstvo podrazumijeva 'budnu i zainteresovanu javnost' koja prati šta se dešava u politici, zdravstvu, obrazovanju, zapošljavanju i svim drugim oblastima od javnog interesa, ukazuje na probleme i koja aktivno učestvuje u političkom životu svoje zemlje. Biti aktivan građanin ne zahteva poseban status i sposobnosti jer svaki pojedinac može biti aktivan građanin, ukoliko se angažuje i zastupa opšti interes. Suština aktivnog građanstva je kapacitet građanina da uoči i adresira problem od javnog značaja, preuzimajući na taj način odgovornost za brigu o zajedničkim dobrima." ${ }^{87}$ Aktivno građanstvo je i dalje nedovoljno razvijeno u EU, budući da se samo $12,6 \%$ građana EU može podvesti po ovaj pojam. ${ }^{88}$ Lahuzen i Tejz (Lahusen \& Theiss) ističu da su politička osvešćenost, znanje i aktivne participacije (na primer, učešće na izborima, članstvo u građanskim organizacijama i učešće u građanskim inicijativama) ključne odrednice aktivnog građanstva koje vode ka razvijanju transnacionalne solidarnosti, budući da građanima EU pružaju građanske veštine, koje su im neophodne kako bi se uključili u podršku prava drugih Evropljana. ${ }^{89}$ Prema istraživanju Lahuzena i Tejza, građani Unije su uglavnom uključeni u inicijative

85 Malcolm Ross, "Transnational Solidarity: A Transformative Narrative for the EU and its Citizens?", op. cit., p. 220.

${ }^{86}$ Ivan Milovanović, "The Experience of COVID-19 Pandemic and Solidarity in the European Union”, op. cit., p. 165.

${ }^{87}$ Lidija Knežević, Aktivno građanstvo i važnost obrazovanja građana, Evropska komisija, Hrvatska, 2017, Internet: https://epale.ec.europa.eu/hr/blog/aktivno-gradanstvo-ivaznost-obrazovanja-gradana-active-citizenship, 04/05/2021.

${ }^{88}$ Giuseppina Guagnano and Isabella Santini, "Active Citizenship in Europe: The Role of Social Capital", International Journal of Sociology and Social Policy, vol. 40, no. 1-2, p. 80.

${ }^{89}$ Christian Lahusen and Maria Theiss, "European Transnational Solidarity: Citizenship in Action?", American Behavioral Scientist, vol. 63, no. 4, 2019, p. 446. 
i akcije solidarnosti na nacionalnom nivou, kao izvan Evropske unije, sa samo jednim od četiri ispitanika posvećenih podršci drugim građanima EU. ${ }^{90}$

\section{Zaključak}

Budućnost Evropske unije nakon pandemije Kovid 19 trebalo bi da se gradi na novom evropskom narativu kojim se promovišu aktivno građanstvo i transnacionalna solidarnost, kako bi se savladao problem u komunikaciji između Unije i njenih građana, kao i problem nedostatka inicijativa građana EU za pokretanje političkih debata „o specifičnim evropskim pitanjima na nivou koji bi predstavljao izazov za nacionalne vlade". ${ }^{91}$ Novi evropski narativ, zasnovan na ideji razvijanja aktivnog građanstva i transnacionalne solidarnosti, doveo bi do preosmišljavanja ideje evropskog identiteta i prevazilaženja binarnih opozicija na kojima se temelji ideja evropskog identiteta, a koje su najizraženije u vremenu kriza. lako se aktivno građanstvo promoviše u okviru brojnih evropskih inicijativa i programa, ${ }^{92}$ ono se uglavnom vezuje za inicijative solidarnosti u okviru samih država članica. ${ }^{93}$ Stoga su neophodne evropske inicijative kojima će se promovisati pojam aktivnog građanstva zasnovan na ideji transnacionalne solidarnosti, koja obuhvata razvijanje i unapređivanje solidarnosti i među državama članicama EU, i među njenim građanima.

\section{Literatura}

Bee, Cristiano, Active Citizenship in Europe, Palgrave Macmillan, London, 2017. Della Sala, Vincent, "Political Myth, Mythology and the European Union", Journal of Common Market Studies, vol. 48, no. 1, 2010, pp. 1-19.

\footnotetext{
90 Ibid., p. 454.

91 Jovana Marović, „Aktivno građanstvo kao preduslov za razvoj demokratije u Evropskoj uniji" u: Slobodan Samardžić i Ivana Radić Milosavljević (urs.), Evropski građanin u vremenu krize, Fakultet političkih nauka Beograd, 2013, str. 163.

${ }^{92}$ Cristiano Bee, Active Citizenship in Europe, Palgrave Macmillan, London, 2017.

${ }_{93}$ Christian Lahusen and Maria Theiss, "European Transnational Solidarity: Citizenship in Action?", op. cit., p. 454.
} 
Guagnano, Giuseppina and Santini, Isabella, "Active Citizenship in Europe: The Role of Social Capital", International Journal of Sociology and Social Policy, vol. 40, no. 1-2, pp. 79-98.

Ivić, Sanja, „Kriza evropskog identiteta” u: Aleksandar Gajić, Milan Igrutinović (urs.), Kriza Evropske unije: Okviri, dometi, trendovi, Institut za evropske studije, Beograd, 2013, str. 205-218.

Koeck, Heribert Franz, "Solidarity in the European Union", Albolafia: Revista de Humanidades y Cultura, no. 16, February 2019, pp. 85-92.

Lahusen, Christian and Theiss, Maria, "European Transnational Solidarity: Citizenship in Action?", American Behavioral Scientist, vol. 63, no. 4, 2019, pp. 444-458.

Marović, Jovana, „Aktivno građanstvo kao preduslov za razvoj demokratije u Evropskoj uniji", u: Slobodan Samardžić i Ivana Radić Milosavljević (urs.), Evropski građanin u vremenu krize, Fakultet političkih nauka Beograd, 2013, str. 163-174.

Milovanović, Ivan, "The Experience of COVID-19 Pandemic and Solidarity in the European Union", in: Ivan Stanojević (ed), Political Consequences of the Pandemic, The Serbian Political Science Association, Belgrade, 2021, pp. 163-179.

Riker, Pol, Vreme i priča, tom 1, Izdavačka knjižarnica Zorana Stojanovića, Sremski Karlovci, 1993.

Ross, Malcolm, "Transnational Solidarity: A Transformative Narrative for the EU and its Citizens?", Acta Politica, vol. 56, no. 3, 2021, pp. 220-241.

Stråth, Bo, "A European Identity: To the Historical Limits of a Concept", European Journal of Social Theory, vol. 5, no. 4, 2002, pp. 387-401.

Vujačić, Ivan, "Evropska unija - transformacija ili raspad” u: Mihail Arandarenko, Ivan Vujačić (urs.), Evropska unija i Srbija: Od tranzicije do pridruživanja, Ekonomski fakultet, Beograd, 2012, str. 13-23.

Williams, Andrew T., "Taking Values Seriously: Towards a Philosophy of EU Law", Oxford Journal of Legal Studies, vol. 20, no. 3, 2009, pp. 549-577. 


\title{
THE FUTURE OF THE EUROPEAN UNION AFTER THE COVID - 19 PANDEMIC: CREATING A NEW NARRATIVE FOR EUROPE
}

\begin{abstract}
The COVID-19 pandemic had an important impact on internal political relations in the European Union, as well as on the position of the European Union as a global actor. At the domestic political level, the European Union has faced the erosion of the principle of solidarity as one of its fundamental principles, given that in finding solutions for the protection of the health and economies of EU member states, national rather than common European interests have dominated. The main thesis on which this paper is based is that it is necessary for the European Union to develop a new narrative based on the concept of transnational solidarity, which will contribute to greater efficiency and responsibility of the EU. Unlike the idea of solidarity at the level of nation states, the development of the idea of European solidarity should include the multilayered, supranational nature of the European Union, and solidarity should develop both among the EU member states and citizens of the European Union (through further development and promotion of active citizenship)..
\end{abstract}

Keywords: European Union, COVID-19, crisis, solidarity, narrative. 